\title{
The Articulation of Different Life Domains among Female Senior Managers and Their Subjective Well-Being: Focusing on Meaning Constructions in Everyday Life
}

\author{
María del Río Carral ${ }^{1}$ \\ ${ }^{1}$ Institute of Psychology, University of Lausanne, Lausanne, Switzerland \\ Correspondence: María del Río Carral, Insitute of Psychology, University of Lausanne, Mouline, 1015, Lausanne, \\ Swizterland. Tel: 41-21-692-3284.E-mail: maria.delriocarral@unil.ch
}

Received: July 16, $2015 \quad$ Accepted: August 11, $2015 \quad$ Online Published: August 13, 2015

doi:10.5539/ijps.v7n3p157

URL: http://dx.doi.org/10.5539/ijps.v7n3p157

\begin{abstract}
Work-life issues have become a major concern across Western societies with the objective to promote women's careers and well-being. However, despite growing attempts to increase the number of women in senior management positions in European countries, such as Switzerland, they remain highly underrepresented. Inspired from the cultural approach in psychology, this article focuses on these women's concrete everyday life to understand how they articulate different life domains and how this influences their subjective well-being. A narrative approach based on reflexivity is adopted to analyze women's activity. Results show meaning intertwinements between life priorities that are often conflicting. Two psychological functions are identified: the feeling of control and the letting go of control. Each of these contributes to women's subjective well-being through the use of diversified supports, but their structuring roles appear only in relation to one another. Results are discussed in the light of existing literature and of their implications.
\end{abstract}

Keywords: critical psychology, female senior managers, subjective well-being, work-life balance, work-life conflict

\section{Introduction}

In recent decades, important transformations in Western societies have entailed fundamental consequences in regard to the organization of work and life, henceforth considered as articulated universes. Among these changes, there has been a rapid growth of women's involvement in the labor market and the subsequent urge for gender equity (Acker, 2006; Campbell Clark, 2000; European Commission, 2010, 2014; Lewis \& Cooper, 1999, West \& Zimmerman, 1987). In European countries, important political and institutional efforts have been undertaken to support women in advancing their careers. Work-life issues and their impact on women's health have received particular attention to better promote female participation in decision-making jobs.

Moreover, new modes of work built around projects and networking have emerged. While these modes have brought more autonomy and flexibility in the organization of work duties and responsibilities, they are also very demanding because of their strong focus on productivity, efficacy and individualization (Boltanski \& Chiapello, 1999).

At the crossroads of these crucial transformations, the situation of women working as senior managers in contemporary industrialized societies becomes emblematic to better understand how work and other life priorities are concretely articulated given a demanding changing context, and how this process influences their subjective health and well-being. Their activity in leading positions is characterized by: the intensification of work related to project management; the accomplishment of brief diversified tasks; the fragmented nature of work, and the dominant character of the relational and affective dimension (Agypt \& Rubin, 2012; Clough \& Halley, 2007; Ehrenberg, 1991; Karvar \& Rouban, 2004). In addition, women remain mainly responsible for household work and (child) care duties (UNECE, 2013). Moreover, as suggested by Little and her colleagues, leaders' health deserves further attention in research despite its complexity, both on its positive and negative states (Little, Simmons, \& Nelson, 2007). Indeed their health may impact at organizational level, because of the key position they occupy within the organization as a whole.

An abundant literature within the social sciences has emerged along with the social changes that have been 
underlined. Amongst this body of research, it is possible to identify two main trends related to the study of the articulation of different life domains and its impact on women's health and well-being.

The first stream defines such articulation as the conflict that results from coping with incompatibilities regarding two main realms, work and family. Authors in this trend have been greatly inspired by Karasek's seminal work on "stress" (Karasek \& Theorell, 1990), adopting mostly a quantitative perspective. Among them, Kahn and his colleagues first developed the "role theory" (Kahn, Wolfe, Quinn, Snoek, \& Rosenthal, 1964), characterized by the negative spill over effect of work and family roles on health. To some authors, this tension results from the double burden of professional and domestic duties, where the latter weigh more heavily on women than on men (Artazcoz, Borrell, \& Benach, 2001; Harenstam \& Bejerot, 2001; Messing, 1999). Others have focused on the negative impact of a heavy workload on employees' health because of its interference with family life (Eby, Casper, Lockwook, Bordeau, \& Brinley, 2005; Geurts, Taris, Kompier, Dikkers, van Hooff, \& Kinnunen, 2005). The "conservation of resources model" (Marks, 1977) also studies work and family demands as conflicting by stating that time and energy resources tend to decrease when juggling between work and family roles (Fisher, Bulger, \& Smith, 2009; Greenhaus \& Powell, 2006; Voydanoff, 2005). Moreover, research has underlined the beneficial impact of flexible schedules, job control, and social support, whose influence moderates stress from work demands (Byron, 2005; Grönlund, 2007; Hammer, Neal, Newsom, Brockwood, \& Colton, 2005). However, disparities have been shown concerning the stressful effect of schedule control (Chesley, 2005; Kelly, Moena, \& Tranbyb, 2011). Finally, authors interested in state and institutional policies have observed the alleviating effect of family conciliation strategies to reduce "work-family conflict" (Grönlund \& Javornik, 2014; Braun, Lewin-Epstein, Stier, \& Baumgärtner, 2008) although, once again, international research presents inconsistencies as highlighted by Jang and his colleagues (Jang, Park, \& Zippay, 2011).

The second stream promotes balance between different life domains, that is, how their articulation is related to health and well-being (Greenhaus \& Powell, 2006). While certain authors have targeted the enrichment brought by work and family roles (Hanson, Hammer, \& Colton, 2006), others have studied the enhancement of subjective well-being by promoting "work-life balance" (Diener \& Seligman, 2004; Rego, Pina, \& Cunha, 2009). Subjective well-being is defined in this view as a broad construct including cognitive and affective reactions to life when biological needs, psychological needs, and leisure activities are fulfilled (Diener \& Ryan, 2009; Newman, Tay, \& Diener, 2014). Certain authors have broadened the "work-family" perspective to explore the beneficial effect of non-professional practices outside family life on work performance (e.g., physical activity, leisure, social support, cultural activities, etc.) (Fisher et al., 2009; Hecht \& Boies, 2009). Hence, non-professional practices can relieve job stress and enhance subjective well-being, and job stress can be moderated by the expression of emotions in other life domains (Jansen, Kant, Kristensen, \& Nijhuis, 2003; Moreno-Jiménez, Mayo, Sanz-Vergel, Geurts, Rodriguez-Muñoz, \& Garrosa, 2009).

Whether focusing on "conflict" or on "balance", these two trends have led authors interested in women, work, and health to broaden their perspective to a more integrated vision of these themes. Stress and subjective well-being can henceforth be defined as complex processes that outstep the pure impact of working conditions on health, by taking into consideration influences stemming from other life domains. Yet, this general overview points out the need to further investigate how different types of activities - such as work, leisure practices, cultural activities, social activities, physical activities, family duties, and social support — can become beneficial, namely to women, from their own point of view. Existing research, however, has majorly overlooked sense-making in its analysis of the influence of such activities across life domains. This is mainly due to the dominant use of standardized scales to assess stress, depression, subjective well-being, quality of life, and job satisfaction, through quantitative approaches that are not based upon concrete life situations. Besides, many studies tend to relate subjective well-being and low stress levels to a state of "equilibrium" that is to be reached between work-family or work-life. In other words, both trends, by decreasing conflict and struggle between different life priorities, pursue the "ideal" of the "right" balance between life priorities (COST A34, 2009; Fisher et al., 2009; Jansen et al., 2003; Moreno-Jiménez et al., 2009), and in doing this, subjective meaning related to concrete practices tends to be widely overlooked.

This article aims to contribute to fill in these gaps. As underlined by several authors on the field, more comprehensive approaches need to be developed (Campbell Clark, 2000; Johnson, Lero, \& Rooney, 2001; Thompson \& Bunderson, 2001). My field study is qualitative. It focuses on female senior managers in order to identify how they develop strategies and supports across different domains of their everyday life, and how this may contribute to their subjective well-being through their meaning. The research has been conducted in the context of Switzerland, which among rich countries, is particularly challenging to working women in regard to work-life issues, despite the efforts undertaken in this direction (Dutu, 2014). Its theoretical framework is 
inspired by the cultural approach in psychology (Ratner, 1997; Vygotsky, 1997, 1999). This choice is underpinned by the potential of this perspective to highlight the central role of meaning that emerges through activity anchored in daily life across different life domains. Psychological phenomena are hence understood in relation to their specific sociocultural setting (Engeström, Miettinen, \& Punamäki, 1999; Ratner, 1997). In this sense, values, norms, and rules cannot be reduced to variables; on the contrary, they are pivotal entities that organize and structure psychological processes. At the same time, they are continually interpreted and transformed by human beings through meaning (Engeström et al., 1999). Therefore, language is not merely representational; it is rather a psychological instrument (words as socio-cultural signs) used through individuals' activity to transform their social realities and their own self and psychological processes (Engeström, et al., 1999; Vygotsky, 1997). Within this perspective, subjectivity can be viewed as "intersubjective" given its social and historical anchorage (Santiago-Delefosse, 2014).

The next section presents the qualitative method that was implemented. Based on accounts of concrete activity, it was designed in order to enable self-reflexivity among female senior managers to access meaning constructions on their lived experience. I will then describe the main results, illustrated through women's accounts. They will be discussed in the light of existing literature, considering their implications regarding subjective well-being in relation to the articulation of different life domains in contemporary industrialized societies.

\section{Method}

\subsection{Sociocultural Context of the Research}

As highlighted by Bruner (1990, 2002), research needs to integrate "real life" situations and socially embedded narratives produced by "real people". This is why this study focuses on female senior managers who work in a specific context.

The Swiss context raises important challenges with regard to work-life issues, namely among women occupying positions of high responsibility. Encouraging the advancement of women in their careers has indeed become a major objective in this country (European Commission, 2010, 2014; Federal Office of Equality, 2010, 2012). But recent statistics (OCDE, 2011) show that female participation in senior management positions remains strongly underrepresented (5.7\%) compared to their male counterparts (9.6\%) despite an important integration of women in the labor force (46\%) (Boye, 2009; Dutu, 2014; Thoenen, 2010). In Switzerland, women are also mainly responsible for domestic work and (child) care (UNECE, 2013; Federal Statistical Office, 2013). Indeed, it has been stated that men and women adhere to rather "conservative" values regarding their family life (Dutu, 2014). At the same time, there is also limited provision of child-care facilities and services, only available at a high cost. Although the general trend in the Swiss setting is to adopt a "modified male breadwinner" model (men working full-time and women half-time) (Bühlmann, Elcheroth, \& Tattamanti, 2010), this research will target women working on a full-time basis, or at least $80 \%$, to better grasp how they deal with the highly demanding context they are confronted with.

\subsection{Participant Characteristics}

The sample is composed of 20 women senior managers who accepted to participate (anonymously) in the study upon being fully informed of its objectives and methodology ( 21 women were originally part of the sample, but one passed away during the time our research took place; also five refusals were recorded and analyzed to improve the initial contact with this group). The size of the sample was determined in relation to the saturation point. Finding women holding senior management positions was not an easy task, given the low rate representing this category in Switzerland. Nevertheless, I was introduced to some of them through third parties. This strategy allowed me to contact women personally via email and to continue to define the sample randomly through the so-called "snowball effect". Participants were Swiss or European. Their average age was 43, a period within the life course when family, work and social responsibilities can be assumed. All participants worked as company or department head in organizations based in Switzerland. The sampling strategy aimed to cover the private sector (namely multinationals) and the public sector, focusing on main domains of activity in the Swiss context: healthcare and pharmaceutical sector, food and micro-technologies. Also, participants' family status was cautiously diversified, so that alternative patterns to the "traditional" work-family configuration could be included in the research: eleven women lived with a partner and nine of them lived alone. In addition, six of them had children under fifteen; nine of them had children over fifteen, and five of them were childless (see Appendix A).

From a qualitative point of view, the main interest lies in the inclusion of a relatively wide spectrum of lived experiences regarding different life status. This diversity also constitutes a valuable insight in the analysis of data (Mason, 1996). At the same time, the systematic and random sampling procedure allows for generalization, 
under the condition that a group with similar characteristics is defined.

\subsection{Procedure}

In accordance with the research objectives and the sample's characteristics (tertiary level education, an increased cultural capital), a qualitative method was designed to collect our data (Note 1). This method aimed at producing narrative material (Brown, Stacey, \& Nandhakumar, 2007) to understand how women make sense of their daily activity across life domains through an inductive approach (Riessman, 2008). Two concepts inspired this design: activity and reflexivity (del Rio Carral, 2014). The concept of activity was mobilized because of its potential to embrace the lived experience as a whole. While it allows to consider explicit and observable behaviors, gestures, practices grounded in concrete domains of daily life (different organizations and institutions conveying rules and norms), it also gives access to meaning constructions that are implicit and non observable (intentions and values), yet related to explicit behaviors. As stated by different authors (Vygotsky, 1997; Engeström et al., 1999), activity links the social and the situated dimensions of human behavior to the psychological dimension of attitudes that underpin them. Concerning reflexivity, this notion refers to the human capacity to turn back upon lived experience as part of the sense-making process (Lyons \& Chamberlain, 2006; Mead, 1963; Ratner, 1997; Vygotsky, 1999).

Underpinned by the previous premises, the method implemented enabled participants' reflexivity in order to access meaning given to activity indirectly (Vygotsky, 1997), that is, in two steps. By first focusing on the description by participants of observable fulfilled practices across different life domains, its technique enabled the production, during a second stage, of the intentions and values related to these practices:

During the first stage (Time 1 (T1)), a structured in depth interview (1-2 hours per interview) was conducted to guide women throughout the factual and detailed description of observable behaviors having been performed the day before across different domains, as a "snapshot" of a complete day in their life (immediate lived experience). At this point, a time interval of six months was introduced to favor temporal and psychological distance toward immediate lived experience, that is, to transfer performed practices to a different context across time and space. In a second stage (Time 2 (T2)), the narrative material from T1 was used to guide in-depth interviews conducted across the same sample (1-2 hours per interview). At this stage, narratives from T1 became new "objects of analysis" to the women themselves through reflexivity, guided by the researcher. In addition, this two-step design allowed participants to position themselves concerning new life events, using their own T1 material as a concrete reference. The introduction of a temporal distance toward performed behavior motivated the production of narratives on expectations, possibilities, desires, and difficulties associated by women with subjective well-being in a self-reflective way. The collection of narratives was completed when data saturation had been achieved, that is when no new relevant information emerges with respect to the object under investigation (Critical Appraisal Skills Programme (CASP), 2006; Miles \& Huberman, 2014; Pope, Ziebland, \& Mays, 2000).

Accounts from T1 and T2 (40 interviews) were fully transcribed (600-800 pages of narratives) and were analyzed exhaustively using two different techniques to enhance the quality of research (Fischer, 2006). The triangulation of methods was made up of a main technique of analysis of all collected data stemming from the narrative approach, namely a thematic analysis (Braun \& Clarke, 2006; Riessman, 2008). In addition, a secondary technique consisted in a lexicometric analysis (Alceste ${ }^{\circledR}$ software), which was used to support interpretation of data. This software processed the vocabulary employed by women in $\mathrm{T} 1$ and $\mathrm{T} 2$ by counting frequencies of co-occurrent words and grouping them into classes (Aubert-Lotarski \& Capdevielle-Mougnibas, 2002; Reinert, 1998). The triangulation strategy enabled to confirm the adequacy of the thematic analysis. The strategy of analysis also integrated dynamics of change concerning women's lives, since narratives produced in $\mathrm{T} 1$ were used to elaborate the interview guides for $\mathrm{T} 2$.

Instead of considering the researcher's influence as a «bias», the cultural approach argues that it is necessary to make this influence explicit (values, presuppositions, cultural belonging, gender issues, etc.) (Danziger, 1994). In adequacy with this premisse, the researcher's reflexivity was included in the study by undertaking a critical analysis of assumptions produced as historically and culturally situated, rather than static facts drawn out of context (Danziger, 1994; Willig, 2001). This self-reflective procedure intended to address the need for research to turn back to itself as to take into account the situated nature of its results (Alvesson, Hardy, \& Harley, 2008; Clegg \& Hardy, 1996). In addition, reflexivity allowed the appropriate distance between theory and the field (del Rio Carral \& Santiago-Delefosse, 2015).

\section{Results}

This section will present main research results. The analysis of women's narratives highlights the central role of work in their accounts on lived experience. Work constitutes a major source of personal fulfillment and 
satisfaction to the great majority of participants. Specificities regarding their accounts on their job as senior managers concern their self-awareness of having: the required qualifications and skills to be able to coordinate several parallel projects; the capacity to face the urge to produce effective outcomes regarding these projects in short periods of time, and the ability to be able to respond to urgent and important demands that can potentially arise at any time. However, all women underline the subjective importance to be enabled to maintain activities that are perceived outside work and/or family life, that is, as "parenthesis" to responsibilities and obligations.

Workplace Autonomy and Flexibility. Overall, interviewees refer to the unpredictable nature of their job, where autonomy and flexibility appear as important qualities. All participants value the significant degree of autonomy, allowing flexibility in time management, which is highly appreciated:

\section{Valentine}

Managing is a multi-criteria procedure, but sometimes these criteria are not necessarily conscious: it's like a picture with a set of balloons and signals and I know where I'm heading! But I didn't necessarily do a logical procedure of analysis to evaluate what is most important in terms of priorities. And if something new arises, then it's not a problem because it's "elastic", in other words, it's open. (T2, q. 8)

Autonomy and flexibility at work seem beneficial not only to efficiently organize priorities stemming from the work domain. These qualities enhance certain "permeability" at psychological level between professional tasks and extraprofessional activities associated to four different life domains (work, family, social and personal lives) (see below Table 1). Meaning given to activity in a specific life domain (e.g., work) emerges in relation to that particular context, but also to what is experienced outside that context, in other life domains involving different expectations, values, norms, etc. that also mobilize women's subjectivity.

Table 1. Definition of four main life domains identified on the basis of thematic analysis of produced data

\begin{tabular}{ll}
\hline Life Domains & \multicolumn{1}{c}{ Description } \\
\hline Work & $\begin{array}{l}\text { Work activities oriented towards project and team management } \\
\text { Job perceptions involve identifying with features related to the type of } \\
\text { activity, its sector and the hierarchical position within the organization }\end{array}$ \\
& $\begin{array}{l}\text { Activities associated with family via interactions with children and/or } \\
\text { partner } \\
\text { Damily }\end{array}$ \\
& $\begin{array}{l}\text { Activities involving strong emotional bonds } \\
\text { Social }\end{array}$ \\
& $\begin{array}{l}\text { Shared social activities with chosen relationships (friends, associative } \\
\text { life, sports, sociocultural activities, etc.) }\end{array}$ \\
& $\begin{array}{l}\text { Activities associated with being alone in an intentional manner } \\
\text { (embodied and sociocultural) }\end{array}$ \\
& $\begin{array}{l}\text { Emotional life defined by the relationship to another person, namely a } \\
\text { partner }\end{array}$ \\
\hline
\end{tabular}

To illustrate this, the use of social networks (e.g., Facebook) often represents a way to explore friends', partners', and/or children's universes during work time without needing to disturb the flow of professional activity. Also, interviewees allow themselves some space at work to set social appointments with friends by e-mail or telephone; to address health or personal needs by calling the doctor, the hairdresser or the partner; and finally, to plan extracurricular activities for the children (among working mothers).

\section{Elisa (Note 2)}

There are tiny things that take two minutes and that you can sneak into your day, and you cannot group them all together. That is, I could never work in a place where I am not able to take these personal spaces off, because I think that I invest a great deal in my job, I love my job, I have no regrets, but one of the things I appreciate about it is that if I spend eleven hours per day here, it means I am also able to dedicate 30 minutes, 3 minutes, 5 minutes, 2 minutes to other stuff. I couldn't do otherwise. I could not be a cashier at the supermarket or work in an ... Open space office? Yes, where I could not function according to my 
own rhythm. I take a few minutes to check my Facebook: this is not an "official break" because I am at the same time on the phone, attending a professional call. (T1, q. 127-129)

Parallel to permeability, all women describe the subjective need to build psychological boundaries meant to separate the lived experience related to each life realm as distinct from the rest of their day-to-day, but most of all, to preserve their experience in a certain time/space from obligations and responsibilities regarding other life domains. This dissociation constitutes a widely shared strategy among participants, signified as indispensable to feel less strained and more relaxed. According to narratives, psychological boundaries are enhanced through the possibility to change from one activity to another one, thereby influencing spatial, temporal, social and corporeal dimensions. This possibility to shift activities goes hand in hand with clear changes in women's intentions and attitudes.

\section{Carla}

So you never think about it in the car on your way home? No, never! Or rarely, because just before leaving I will take some time to conclude my working day and to put things in their own "little box" I'd say, so in the evening it's over, I do not think about work anymore. I am quite lucky to have a moment on my own to drive home, so I may listen to the news on the radio, so I turn the page when I arrive home if it's not a particularly busy period at work, you see? (T1, q. 45)

As confirmed through Carla's narratives in T2, it seems particularly important to be able to steer activity in different environments, so as to perceive the possibility of shifting from one life domain to another. This is signified as a resource that helps this participant to adjust to day-to-day constraints:

\section{Carla}

I fill my "basic needs", I recharge my batteries at home every evening. So then I am ready to head for a new "round", so for me it is extremely important, these moments, I find my resources for the new day to come. (T2, q. 43)

Psychological Functions Emerging from Daily Life. Both, intertwinements and boundaries described by female senior managers are not exempt from "micro-conflicts" stemming from their plural social participation, because of the heterogeneous nature of the experience in different life domains (del Rio Carral et al., 2009; del Rio Carral, 2014). Yet, these tensions between professional and nonprofessional priorities may give rise to various supports that can be implemented and used through activity in daily life by participants.

More particularly, there is a dialectical tension between two poles, each of them defined by a psychological function that plays a specific role in participants' subjective well-being. One of these poles concerns the feeling of control over daily responsibilities, and the other is defined as the letting go of control. Both poles become an integral part of subjective well-being when signified by women in relation to one another. They reveal constant adjustments that emerge as meaningful responses by interviewees to different social and embodied constraints experienced in daily life as: senior managers, women, companions, mothers, friends, etc.

Feeling of control. The first psychological function related to subjective well-being refers to the feeling of control, appearing across narratives as a necessity to be able to cope with numerous responsibilities, duties and obligations. Signified as a source of satisfaction, the feeling of control is most often associated with the work and family domains through the use of organizational supports. The latter include: the implementation of a routine outside work to facilitate domestic and family chores as opposed to the flexible nature of senior management activities at work; the anticipation and organization of work and family obligations through diversified strategies involving the use of written language (e.g., "to-do" lists, post-its, agendas), and finally, access to institutional supports that give structure to the day-to-day organization (e.g., maternal leave, parental leave, claiming a cut in work hours, etc.).

Furthermore, the feeling of control described in narratives requires the specific engagement of women in activity following a constant and intensive pace, namely focused at performing for practical purposes, and efficiency oriented. While organizational supports help an efficient adjustment to duties characterizing senior manager positions (meetings, travelling, coordinating projects, etc.), they are also used by women to better articulate (child)care and/or school schedules, extracurricular activities for children (among mothers), housework, meals, etc. Indeed, interviewees feel mainly responsible not only for work obligations, but for most issues outside work too.

\section{Elisa}

It is a lot of organization, but at least it works for me. I try to write everything down because I believe that 
it allows you to find all the remaining "spaces" in your schedule. If you go through your list, you say: "well, now I have ten minutes so that I do not have enough time to do this or that, but I can write this little e-mail indeed". So that's it, that's how I manage. It is a mix of "what is important?" and "what is urgent?". Besides, I know naturally how much time each activity will take, more or less. So the activity of writing things down helps you to feel in control? Oh totally, yes, yes! Because I find that even the calendar does not show enough details... (T2, q. 6-7)

But beyond the pragmatic role of organization, the feeling of control can also respond to another concern, yet less developed in women's narratives. This concern is signified by a blurred feeling of anxiety related to the changing, demanding and unpredictable nature of participants' working context. Their engagement through complex organizational supports following an intensive pace of constant activity could hence represent a strategy in some cases:

Elisa

I think that if we sit down and rest and say: "ok, I am happy, I love my kids, I love my work, I love my family", well, tomorrow you loose everything! So you must never stop moving. Even to find a certain balance, always keep on moving. (T2, q. 61)

Finally, the ability to cope with work and family duties through organization can also provide women with a sense of "structure" regarding the day-to-day that seems profitable from their perspective. In particular, it allows free time for the development of activities outside work and family obligations. This strategy seems common to all interviewees, although participants with small children (under 15) find this more challenging than those with children aged over 15 or childless. It is important to note that some working mothers may nevertheless succeed in creating these spaces. Anna for instance is the mother of a four year-old. Because she works far from home, she is able to free time for herself, despite a heavy schedule involving daily trips for professional and family reasons.

\section{Anna}

It's how time is used, organization means being able to use time in the best possible way, so as to be able to take advantage, simply that, being able to group things together so as to free other spaces, and then being able to use them as in a profitable way. (T2, q. 13)

In sum, the psychological function related to the feeling of control is enabled among female senior managers through complex organizational supports. The latter are implemented according to their role to each woman, given her life context. The structuring value of supports is linked to their potential in coping with experienced institutional constraints, often professional and domestic. Also, women adjust by these means to a changing and unpredictable context at work. Finally, the feeling of control allows participants to free spaces that can be experienced outside the highly structured framework defined by their work and/or family lives. In this regard, it contributes to subjective well-being only when experienced in tension with the function described here below.

Letting go of control. The second psychological function that contributes to subjective well-being, on the basis of interviewees accounts, is the letting go of control. Interacting dialectically with the feeling of control, this function addresses an issue made explicit by most interviewees: the subjective awareness of needing to distance oneself from daily institutional constraints. This process is defined as the participants' ability to step out from certain duties, concerns and responsibilities (very often, but not always, from work and family lives), temporally and spatially, in order to achieve psychological detachment within a limited context and period of time. Activities associated with this second function mostly belong to the social and personal domains, even if some interviewees may refer to family and work activities as enhancing the letting go of control, depending on their intention and value in a given context. An excerpt from Dalia's narratives reveals how the mechanical gesture involved in washing the dishes is signified as a moment of escape, aimed at letting go on the psychological level:

Dalia

It is interesting to note that washing the dishes is related to well-being for you. Yes, because it's a mechanical gesture and the mind wanders. Actually it's an activity where I can think about anything I want, work if I want to, or anything else, since I don't need to focus when I do it. It's a moment of escape! (T2, q. 31)

This example shows the subjective importance to women of perceiving the possibility to engage in practices underpinned by the intention of letting go of control. Very often, this may be achieved through diversified embodied and sociocultural supports, used by women to actively create their own personal space. In Dalia's case, the embodiment of an automatic and repetitive gesture is associated with a moment of "escape" that releases her 
mind from certain professional concerns, at least momentarily. Other activities call for the voluntary withdrawal from social interactions (e.g., meditate, stare at a landscape, go for a walk or for a drive, smoke a cigarette, etc.). Physical activities (swimming, skiing, walking, cooking, etc.) and sociocultural activities (travelling, reading, watching television, painting, going to a museum, to the theatre or to the movies) can also become means to let go of control by using the body and/or cultural tools that evoke sensations and feelings that are experienced as satisfactory, relaxing, agreeable or revitalizing.

In the following example, Beatrice describes the beneficial role of engaging in physical activities that are qualitatively different from one another, belonging to different contexts. One of them is related to positive sensations stemming from her own corporeality; the other underlines the subjective need to be in touch with nature in order to attain a state of meditation.

\section{Beatrice}

The type of sport that I practice the most is an outdoor sport. Yet, I also practice Pilates, which is rather indoors. However, it is more for relaxing, because it's like yoga, it helps me to relax physically and also to establish a link with my own body. But the outdoor sport is rather to seek a bond with Nature. This allows me to distance myself from... it allows me to reach this meditation mood (T2, q. 29)

Regarding sociocultural activities, Florence's accounts reveal that going to the theatre can have an influence upon her psychological state, in the sense that it helps her to relate her difficulties at work to the difficulties that actors may also experience in their work. This process plays an important role by introducing the possibility, on the psychological level, of distancing oneself from a given life domain, in this case professional.

\section{Florence}

There is pleasure, which is essential to me. I go to the theatre. What I like about it is that it is real, not like the movies. I have the impression of reaching another universe. And that world is in another time; and even if this time can be stressful to people playing on the stage it doesn't compare with what I experience at work, because I am just a spectator. But beyond what I see on stage, I also feel what they experience backstage, they also have a job and they also play a role. That's fascinating! (T2, q. 64)

In some cases, imagination is mobilized to open up new possibilities in women's lives: daily concerns or difficulties can be put into perspective through social exchange, enabling participants to learn from other life stories or the human condition more generally. Thus, daily challenges may become new objects of thought through reflexivity, and sometimes lead to action as the fruit of this process. Creativity and imagining possibilities can help female senior managers to alleviate experienced difficulties and, eventually, find solutions to them.

Isabelle

I like to go trekking on my own, I love to walk in the desert because there is like a call; it soothes me. Sometimes I say to myself "but after all you are in an office with plenty of modern stuff, you earn money". Then, when I find myself in this basic world I enjoy it because I am able to find basic resources, I get to approach different people who talk about their daily lives, and then you realize that you have to stop complaining. I also love the silence of the desert, the peacefulness revitalizes and soothes me; most often I go there alone. My husband does not come with me because in this scenario, I think of it as a space of my own. T2 (q. 11)

So, given the results on two interrelated poles defining psychological functions, this section can be concluded by stating that subjective well-being engages corporeal, social and psychological dimensions through diversified activity, through the mobilization of different types of supports with specific intentions:

\section{Anna}

It's a total duality between a very strict organization and a rapid tempo opposed to a total absence of rules, of complete inactivity! Yes, you define yourself as an organized person yet you need moments of rest and inactivity, with no rhythm or rules. Just letting go. (T2, q. 36-37)

Therefore, letting go of control can go hand in hand with perspective taking on the psychological level, but only in relation to the feeling of control experienced in certain life domains. Based on this analysis, subjective well-being emerges as a process rather than a state. Its complexity relies on the permeability and dissociation of meaning constructions emerging from a multiple and active social participation of female senior managers. It is important to note however, that specific social and physical conditions in critical life events can impede the possibility of developing meaningful activity. These living conditions have been reported elsewhere (del Rio 
Carral, Fasseur, \& Santiago-Delefosse, 2009; del Rio Carral, 2014).

\section{Discussion}

Previous research on the articulation of different life domains has widely explored this phenomenon from a macro-level interest in gender and family policies within organizations, as well as at individual level, geared toward the dominant use of standardized instruments to assess stress and subjective well-being (Allis \& O'Driscoll, 2008; Brough, O'Driscoll, \& Kalliath, 2005; Casper, Eby, Bordeaux, Lockwood, \& Lambert, 2007; Eby et al., 2005). From a critical standpoint, several authors have underlined the need for its broader consideration in research, beyond the "work-family" dyad (Kossek, Lewis, \& Hammer, 2010; Lambert, 1990; Ozbilgin, Beauregard, Tatli, \& Bell, 2011). Through this study, I have raised this issue by focusing on the concrete daily life of female senior managers working in high responsibility jobs. The results have underlined the role of engaging in diversified activity in subjective well-being. Activity is always embedded in different life domains (work, family, social and personal lives), each of which conveys rules, norms, and values, often conflicting in terms of expectations (Henriques, Hollway, Urwin, Venn, \& Walkerdine, 1984). Contradictions and conflicts between different life priorities seem part of daily life, at least to a certain extent (Henriques et al., 1984).

Furthermore, female senior managers seem confronted with a particularly complex system of activities, where tensions can give rise to the use of supports aimed at coping with a highly demanding life context, characterized by unpredictability and change inherent in their job. Among these women, narratives appear in terms of intertwinements and dissociations between meanings given to activities grounded in different life domains. Their positive value is hence signified through a relational perspective (Ratner, 1997) in regard to one another, not only at pure cognitive level, but also through affects, corporeality and sociality. Autonomy and flexibility are two features characterizing senior management positions, which have proved to reinforce this mechanism. Also, the significant progress of technology contributes to permeability across life domains with the use of smartphones, computers, tablets, etc., especially among populations who have a privileged access to these supports, such as those who work in senior management positions (Kossek \& Lautsch, 2012). However, these women are led to set boundaries to preserve themselves from professional or family demands.

On the basis of the mechanism reflecting the articulation of different life domains, two psychological functions can be highlighted: the feeling of control and the ability to let go of control. A great body of quantitative research has assessed the impact upon well-being of each of these features separately, but the qualitative access to meaning constructions has allowed this study to envisage the links between concrete social constraints and psychological meanings, as well as the influence of the body, feelings, and sensations (Cornish, 2004; Cromby, 2007; Laurier, McKie, \& Goodwin, 2000; Lyons \& Chamberlain, 2006; Marks, 2002). Subjective well-being appears in this perspective as closely dependent on the possibility to engage in diversified activity through dialectical intertwinements that contribute to professional and personal growth (Wallon, 1942). In other words, activity in each life domain involves embodied needs, sensations, and social interactions that become manifest through antagonisms (Riegel, 1976; Valsiner \& van der Veer, 2000; Vygotsky, 1999).

Results regarding the feeling of control are coherent with quantitative research to assess the impact of "job control" on reducing stress in "work to family conflict" (Grönlund, 2007). Yet our qualitative approach has brought additional light in understanding women's experience in jobs with high demands and high control and who have flexible work conditions (Lundberg \& Frakenhaeuser, 1999). As underlined by Hoschild (2003), control does not only help to reduce tensions felt between life priorities, but also seems to enhance agency. To our interviewees, organizational supports are defined as resources implemented in specific contexts so as to feel in control in the face of constant demands, not only as senior managers, but also as mothers and as women. The use of organizational supports as portrayed in this study is essential to women to efficiently deal with daily obligations. Moreover, they play a positive role in relation to senior managers specifically, by helping women to adjust to an uncertain environment at work, where urgent and important matters to attend to can arise at any time. But also, the fact of still being mainly responsible for family, care and domestic issues, seems to reinforce women's need for organization and control.

These results may contribute to explain the generalized tendency among women in our study to engage in constant activity, at least in part. Their intensive pace could also be due to the representation of their own position in the life path and in society more generally, in the sense that the pursuit of a career remains extremely challenging for women in many industrialized societies, such as Switzerland. It is hence possible that female senior managers see their work and life situation as the fruit of a personal choice, which they have to stand by, regardless of any obstacles and impediments that they encounter. Indeed, the intense and steady pace of activity 
is often associated with the mobilization of the body as a solid and resilient entity despite tiredness and fatigue. In another article, we report a closer analysis of this aspect by revealing the ambivalences in physical resistance among female senior managers. While this corporeality certainly enables efficiency in some contexts, it also enhances the tendency to ignore any signs or physical symptoms revealing fatigue or pain. This may be a strategy allowing some to better cope with institutional obligations, even if it entails negative consequences for health and well-being (del Rio Carral, 2014). Indeed, the issue of the body cannot be neglected within the field of management, where productivity can be pursued to the detriment of workers' health and well-being; the social dimension of the body is thus inevitably linked to its corporeal dimension (Hardy \& Thomas, 2015).

Considering the previous arguments, measures addressing work-life balance need to be extended beyond the workplace, to help women to implement improved organizational supports, namely to set aside personal spaces outside daily constraints and structures. This change would be beneficial especially to mothers, by improving childcare services, promoting external caring responsibilities, and facilitating flexibility in duty sharing as the Swiss sample has revealed (Costa, Sartori, \& Åkerstedt, 2006; Grönlund, 2007). Indeed, as Bianchi and colleagues (Bianchi, Milkie, Sayer, \& Robinson, 2000) have suggested, employed mothers may experience a greater dilemma in reconciling work and family duties within the Swiss context, among other things due to the cultural expectations of devotion to children and the home. This might be particularly the case in our study given its dual focus on a sociocultural context with rather traditional views on family life and the gendered division of labor (Dutu, 2013; Fagnani, 2002; Nomaguchi, Milkie, \& Bianchi, 2005), on the one hand, and a societal environment characterized by political and economic changes that have increasingly transformed the organization of work in management positions, on the other. A close analysis of results shows that women with children under 15 working as senior managers do not necessarily experience difficulties in responding to work and family obligations, because they seem to reconcile both life domains through constant organization. However, they may encounter a greater challenge in implementing personal spaces to develop both personal and social activities. Further research is still clearly needed to develop this argument. Besides, the influence of women's age, professional experience, and working status of their partner, on their subjective well-being, needs further investigation.

Critical approaches to the detrimental effects on health and well-being of current transformations of the labor market have been taken by some authors (Allvin \& Aronsoon, 2003). They argue in particular that organizational flexibility stresses employees' individual responsibility in defining their own priorities and drawing their own boundaries between work and life. The ambivalence characterizing the regulation of work shows that flexibility and autonomy can be both structuring and burdensome for subjective well-being, witnessing the complexity underlying the human experience.

The function defined by the letting go of control points out the central role that possibility and spontaneity play in subjective well-being (Malrieu, 2000). This seems particularly true in the context of this study, where women lead an intense daily life, characterized by constant demands, numerous responsibilities and important organizational skills. The release of control is signified as a need, yet circumscribed to specific contexts, especially those allowing for the purposeful implementation and use of physical and/or sociocultural supports. Here again, results confirm the primal role of corporeality (Cromby, 2007; Santiago-Delefosse, 2014) across women's accounts, since it enables them to let go through relaxation, physical exercise, breathing sensations, etc. This finding has been previously discussed in the literature, where authors have claimed the positive impact of physical activities to release job stress (Bryce \& Haworth, 2002; Fisher et al., 2009; Hecht \& Boies, 2009). My approach is nevertheless complementary to existing research. Through its focus on concrete activity, it takes into account the structuring role of context in meaning constructions that guide the use of supports regarding physical activities and corporeality. Besides, the sociocultural dimension defining some activities seems a powerful influence in steering psychological attitudes towards the letting go of control.

Meaning constructions related to the second function underline the central role of "letting go" as a "parenthesis" to existing rules and norms that shape female senior managers' experience as professionals, mothers, partners, and women. Its enablement seems dependent on possibilities that society may offer to rely upon structures providing a certain "backbone" to daily life. In the Swiss context, female senior managers seem to have insufficient structural help, either from the state or at work. Still, the implementation of "free spaces" remains a key support to help female senior managers to let go of control. Improvements are needed to enable these spaces, which should remain outside institutional surveillance so that they may be experienced as an "escape" from daily pressures, routines and social structures. The positive influence on subjective well-being of these "interstices", experienced as an aside from institutional settings, has been previously observed by Roussillon (1996), who highlights their pivotal psychological function in distancing oneself from events or difficulties at work. Their 
positive influence can be extended to other life domains including family, social and personal lives.

As other authors have noted (Newman et al., 2014; Sonnentag, 2012), there is a beneficial impact on subjective well-being of psychological detachment during leisure time to support mental disconnection from work (ex. watching television, walking, doing sports, etc.). In this regard, Kubey and Csikszentmihalyi (2013) have analyzed the role of watching television, defined as an optimal leisure activity helping individuals to relax as well as recuperate. Yet the relational character of this function needs to be integrated in existing approaches on work-family conflict and work-life balance. Indeed, the intentional and purposeful traits that define the artistic, social, associative or political activities seem central to female senior managers, namely because they experience sensations and engage in social interactions that are qualitatively different from the function of control. The self-reflective capacity to put lived events into perspective seems crucial to appraise feelings, thoughts and opportunities from a different standpoint (Mead, 1963; Vygotsky, 1997).

In the present state of this research, the relationship between feelings of control and letting go could be specific to female senior managers in the Swiss context, given highly demanding yet flexible living conditions. These women seem to steer their activity according to a multi-faceted model of self-fulfillment, defined not only by work and family, but also by social and personal lives. As highlighted by Hogue (2010), being a woman and a senior manager remains a challenge in Switzerland, where "women's presence decreases as the hierarchical levels increase. They are quasi-absent on boards of directors and still very few of them dash into the adventure of entrepreneurship" (in Rossi, Borter, \& Sansonnens, 2012, p. 43). This absence of feminine workforce at high levels of the hierarchy could be due to the slow implementation of work-life measures (Federal Statistical Office, 2013; The Economist, 2013) and the lack of state support for leave and care policies (Boye, 2009; Ferrarini \& Sjöberg, 2010; Korpi, 2000; Thoenen, 2010) despite recent encouragements toward gender equality in private and public organizations. Socio-political implications for this category nevertheless call for a broader reflection on how to promote appropriate policies at institutional level that respect spaces of subjectivity exempt from institutional regulation.

To conclude, the interest of conducting research on female senior managers in Switzerland is to consider this case as prototypical in understanding the articulation of life domains and subjective well-being. Research is needed to go beyond the ideal of serenity and balance promoted across major trends in "work-life conflict" and "work-life balance" (Diener \& Ryan, 2009), since discrepancies are inherent in daily life (Riegel, 1976). Research can greatly benefit from qualitative approaches to better explore how concrete life circumstances are experienced through ambivalences regarding their role and effect (Mielewczyk \& Willig, 2007).

At the same time, since qualitative approaches are geared toward the understanding of singularity, variability and complexity (Ratner, 1997), the analyses presented in this article exist in relation to a certain framework and given moment in history (Santiago-Delefosse, 2011; Riegel, 1976). This is why they need to be considered cautiously with regard to their scope and transferability (Danziger, 1994; Vygotsky, 1999). Several limitations can be noted, such as the specificity of the sociocultural context, the size of the sample and the complexity of the methodological design.

Despite its limitations, this study contributes to opening new perspectives in the field, as a cornerstone in understanding how meaning constructions emerging from activity across different life domains influence the embodied, social and psychological dimensions involved in subjective well-being.

\section{Acknowledgments}

I am grateful to Marie Santiago for her helpful comments on a previous draft of this article, as well as Michael Murray and Brendan Gough for their useful advice.

\section{References}

Acker, J. (2006). Inequality regimes: Gender, class and race in organizations. Gender \& Society, 20, 441-464. http://dx.doi.org/10.1177/0891243206289499

Agypt, B., \& Rubin, B. A. (2012). Time in the New Economy: The Impact of the Interaction of Individual and Structural Temporalities on Job Satisfaction. Journal of Management Studies, 49, 403-428. http://dx.doi.org/10.1111/j.1467-6486.2011.01021.x

Allis, P., \& O’Driscoll, M. (2008). Positive effects of non work-to-work facilitation on well-being in work, family and personal domains. Journal of Managerial Psychology, 23, 273-291. http://dx.doi.org/10.1108/02683940810861383

Alvesson, M., Hardy, C., \& Harley, B. (2008). Reflecting on reflexivity: Reflexive textual practices in 
organization and management theory. Journal of Management Studies, 45(3). 480-501. http://dx.doi.org/10.1111/j.1467-6486.2007.00765.x

Allvin, M., \& Aronsson, G. (2003). The future of work environment reforms: Does the concept of work environment apply within the new economy? International Journal of Health Services, 33, 99-111. http://dx.doi.org/10.2190/1D2L-2HV2-0QLL-4PGW

Artazcoz, L., Borrell, C., \& Benach, J. (2001). Gender inequalities in health among workers: The relation with family demands. Journal of Epidemiology and Community Health, 55, 639-647. http://dx.doi.org/10.1136/jech.55.9.639

Aubert-Lotarski, A., \& Capdevielle-Mougnibas, V. (2002). Dialogue méthodologique autour de l'utilisation du logiciel Alceste en sciences humaines et sociales: "lisibilité" du corpus et interprétation des résultats [Methodological dialogue on the use of Alceste in social and human sciences: "readability" of the corpus and interpretation of results"]. 6ème Journées Internationales d'Analyse Textuelle: Saint-Malo.

Bianchi, S., Milkie, M., Sayer, L., \& Robinson, J. (2000). Is anyone doing the housework? Trends in the gender division of household labor, Social Forces, 79, 191-228. http://dx.doi.org/10.1093/sf/79.1.191

Boltanski, L., \& Chiapello, E. (1999). Le nouvel esprit du capitalism. Paris: Gallimard.

Boye, K. (2009). Work and well-being in a comparative perspective: The role of family policy. European Sociological Review, 0, 1-15.

Braun, M., Lewin-Epstein, N., Stier, H., \& Baumgärtner, M. M. (2008). Perceived equity in the gendered division of household labor. Journal of Marriage and Family, 70, 1145-1156. http://dx.doi.org/10.1111/j.1741-3737.2008.00556.x

Braun, V., \& Clarke, V. (2006). Using thematic analysis in psychology. Qualitative Research in Psychology, 3, 77-101. http://dx.doi.org/10.1191/1478088706qp063oa

Brough, P., O'Driscoll, M. P., \& Kalliath, T. J. (2005). The ability of "family friendly" organizational resources to predict work-family conflict and job and family satisfaction. Stress and Health, 2, 223-234. http://dx.doi.org/10.1002/smi.1059

Brown, A. D., Stacey, P., \& Nandhakumar, J. (2007). Making sense of sensemaking narratives. Human Relations, 61(8), 1035-1062. http://dx.doi.org/10.1177/0018726708094858

Bruner, J. S. (1990). Car la culture donne forme à l'esprit. De la révolution cognitive à la psychologie culturelle [Acts of meaning]. Paris: Eshel.

Bruner, J. S. (2002). Pourquoi nous racontons-nous des histoires [Making Stories: Law, Literature, Life]. Paris: Editions Retz.

Bryce, J., \& Haworth, J. T. (2002). Well-being and flow in a sample of male and female office Workers. Leisure Studies, 21, 249-263. http://dx.doi.org/10.1080/0261436021000030687

Bühlmann F., Elcheroth G., \& Tettamanti, M. (2010). The Division of Labour Among European Couples: The Effects of Life Course and Welfare Policy on Value-Practice Configurations. European Sociological Review, 26, 49-66. http://dx.doi.org/10.1093/esr/jcp004

Byron, K. (2005). A meta-analytic review of work-family conflict and its antecedents. Journal of Vocational Behavior, 67, 169-198. http://dx.doi.org/10.1016/j.jvb.2004.08.009

Campbell Clark, S. (2000). Work/family border theory: A new theory of work/family balance. Human Relations, 53, 747-770. http://dx.doi.org/10.1177/0018726700536001

Critical Appraisal Skills Programme (CASP). (2006). Retrieved from http://www.casp-uk.net/

Casper, W. J., Eby, L. T., Bordeaux, C., Lockwood, A., \& Lambert, D. A. (2007). Review of research methods in IO/OB work-family research. Journal of Applied Psychology, 92, 28-43. http://dx.doi.org/10.1037/0021-9010.92.1.28

Chesley, N. (2005). Blurring boundaries? Linking technology use, spillover, individual distress, and family

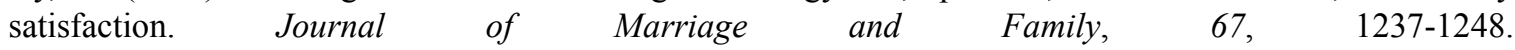
http://dx.doi.org/10.1111/j.1741-3737.2005.00213.x

Clegg, S., \& Hardy, C. (1996). Representations. In S. Clegg, C. Hardy, \& W. R. Nord (Eds.), Handbook of Organization Studies (pp. 676-708). London: Sage. 
Clough, P., \& Halley, J. (Eds.). (2007). The affective turn: Theorizing the social. Durham, NC: Duke University Press. http://dx.doi.org/10.1215/9780822389606

Cornish, F. (2004). Making "context" concrete: A dialogical approach to the society-health relation. Journal of Health Psychology, 9, 281-294. http://dx.doi.org/10.1177/1359105304040894

Costa, G., Sartori, S., \& Åkerstedt, T. (2006). Influence of flexibility and variability of working hours on health $\begin{array}{lllll}\text { and } \quad \text { Intl-being. } & \text { Chronobiology }\end{array}$ http://dx.doi.org/10.1080/07420520601087491

COST A-34 Action. (2009). Gender and well-being: Work, family and public polices. Report core group 5 social movements and well-being for final symposium of Cost Action A-34. Genève: Suisse.

Cromby, J. (2007). Toward a psychology of feeling. International Journal of Critical Psychology, 21, 94-118.

Danziger, K. (1994). Does the history of psychology have a future? Theory \& Psychology, 4, 467-484. http://dx.doi.org/10.1177/0959354394044001

del Rio Carral, M. (2014). Focusing on "A Day in the Life": An Activity-Based Method for the Qualitative Analysis of Psychological Phenomena, Qualitative Research in Psychology, 11(3), 298-315. http://dx.doi.org/10.1080/14780887.2014.902525

del Rio Carral, M., Fasseur, F., \& Santiago-Delefosse, M. (2009). «Porosité» entre vie privée et travail et vie privée, conflits et aménagements: Une étude comparative de deux populations de femmes. Pratiques Psychologiques, 15(2), 155-171. http://dx.doi.org/10.1016/j.prps.2008.09.002

del Rio Carral, M., \& Santiago-Delefosse, M. (2015). Interpretation of Data in Psychology: A False Problem yet a True Issue. Philosophy Study, 5(1), 54-62.

Diener, E., \& Ryan, K. (2009). Subjective well-being: A general overview. South African Journal of Psychology, 39, 391-406. http://dx.doi.org/10.1177/008124630903900402

Diener, E., \& Seligman, M. E. P. (2004). Beyond money: Toward an economy of well-being. Psychological Science in the Public Interest, 5, 1-31. http://dx.doi.org/10.1111/j.0963-7214.2004.00501001.x

Dutu, R. (2014). Women's role in the Swiss economy. OECD, Economics Department Working Papers, No. 1144, OECD Publishing. http://dx.doi.org/10.1787/5jz123dzstkb-en

Duxbury, L., \& Higgins, C. (2001). Work-life balance in the new millennium: where are we? Where do we need to go? Ottawa: RCRPP.

Eby, L. T., Casper, W. J., Lockwood, A., Bordeaux, C., \& Brinley, A. (2005). Work and family research in IO/OB: Content analysis and review of the literature (1980-2002). Journal of Vocational Behavior, 66, 124-197. http://dx.doi.org/10.1016/j.jvb.2003.11.003

Ehrenberg, A. (1991). Le Culte de la performance [The Cult of Performance]. Paris: Calmann-Lévy.

Engeström, Y., Miettinen, R., \& Punamäki, R. L. (Eds). (1999). Perspectives on activity theory. New York: Cambridge University Press. http://dx.doi.org/10.1017/CBO9780511812774

European Commission. (2010). Rapport sur l'égalité entre les femmes et les hommes [Report on equality between women and men]. from http://eur-lex.europa.eu/LexUriServ/LexUriServ.do?uri=CELEX:52009DC0694:FR:NOT

European Commission. (2014). Report on progress on equality between women and men in 2013. Retrieved from http://ec.europa.eu/justice/gender-equality/files/documents/141404_annual_report_en.pdf

Fagnani, J. (2002). Why do French women have more children than German women? Family policies and attitudes towards child care outside the home. Community, Work and Family, 5, 103-119. http://dx.doi.org/10.1080/1366880022010218

Federal Office of Equality. (2010). Work-Family Conciliation. Retrieved from http://equality-office.ch/f/erwerbsleben.htm

Federal Office of Equality. (2012). Federal population survey: Work-family conciliation. Retrieved from http://www.bfs.admin.ch/bfs/portal/fr/index/themen/20/01/new/nip_detail.html?gnpID=2014-545

Federal Statistical Office. (2013). Responsibility of domestic work. Retrieved from http://www.bfs.admin.ch/bfs/portal/fr/index/themen/20/05/blank/key/Vereinbarkeit/02.html

Ferrarini, T., \& Sjöberg, O. (2010). Social policy and health: Transition countries in a comparative perspective. 
International Journal of Social Welfare, 19, 60-88. http://dx.doi.org/10.1111/j.1468-2397.2010.00729.x

Fischer, G. N. (2006). Qualitative Research Methods for Psychologists: Introduction through Empirical Studies. London: Elsevier.

Fisher, G. G., Bulger, C. A., \& Smith, C. S. (2009). Beyond work and family: A measure of work/non-work interference and enhancement. Journal of Occupational Health Psychology, 14, 441-456. http://dx.doi.org/10.1037/a0016737

Geurts, S. A. E., Taris, T. W., Kompier, M. A. J., Dikkers, J. S. E., Van Hooff, M. L. M., \& Kinnunen, U. M. (2005). Work-home interaction from a work psychological perspective: Development and validation of a new questionnaire, the SWING. Work \& Stress, 19, 319-339. http://dx.doi.org/10.1080/02678370500410208

Greenhaus, J. H., \& Powell, G. (2006). When work and family are allies: A theory of work-family enrichment. Academy of management review, 1, 72-92. http://dx.doi.org/10.5465/AMR.2006.19379625

Grönlund, A. (2007). More control, less conflict? Job demand-control, gender and work-family conflict. Gender, Work and Organization, 14, 476-497. http://dx.doi.org/10.1111/j.1468-0432.2007.00361.x

Grönlund, A., \& Javornik, J. (2014). Great expectations: Dual-earner policies and the management of work-family conflict-the examples of Sweden and Slovenia. Families, Relationships and Societies, 3, 147-161. http://dx.doi.org/10.1332/204674313x13796044783891

Hammer, L. B., Neal, M. B., Newsom, J. T., Brockwood, K. J., \& Colton, C. L. (2005). A longitudinal study of the effects of dual-earner couples' utilization of family-friendly workplace supports on work and family outcomes. Journal of Applied Psychology, 90, 799-810. http://dx.doi.org/10.1037/0021-9010.90.4.799

Hanson, G. C., Hammer, L. B., \& Colton, C. L. (2006). Development and validation of a multidimensional scale of perceived work-family positive spillover. Journal of Occupational Health Psychology, 11, 249-265. http://dx.doi.org/10.1037/1076-8998.11.3.249

Hardy, C., \& Thomas, R. (2015). Discourse in a Material World. Journal of Management Studies, 52, 680-696. http://dx.doi.org/10.1111/joms.12113

Härenstam, A., \& Bejerot, E. (2001). Combining professional work with family responsibilities-A burden or a blessing? International Journal of Social Welfare, 10, 202-214. http://dx.doi.org/10.1111/1468-2397.00173

Hecht, T. D., \& Boies, K. (2009). Structure and correlates of spillover from non work to work: An examination of nonwork activities, well-being, and work outcomes. Journal of Occupational Health Psychology, 14, 414-426. http://dx.doi.org/10.1037/a0015981

Henriques, J., Hollway, W., Urwin, C., Venn, C., \& Walkerdine, V. (1984). Changing the subject. Psychology, social regulation and subjectivity. London: Methuen \& Co.

Hochschild, A. R. (2003). The managed heart. Commercialization of human feeling. Berkeley, CA: University of California Press.

Jang, S. J. (2009). The relationships of flexible work schedules, workplace support, supervisory support, work-life balance, and the well-being of working parents. Journal of Social Service Research, 35, 93-104. http://dx.doi.org/10.1080/01488370802678561

Jang, J. S, Park, R., \& Zippay, A. (2011). The interaction effects of scheduling control and work-life balance programs on job satisfaction and mental health. International Journal of Social Welfare, 20, 135-143. http://dx.doi.org/10.1111/j.1468-2397.2010.00739.x

Jansen, N. W. H., Kant, I. K., Kristensen, T. S., \& Nijhuis, F. J. N. (2003). Antecedents and consequences of work-family conflict: A prospective cohort study. Journal of Occupational and Environmental Medicine, 45, 479-491. http://dx.doi.org/10.1097/01.jom.0000063626.37065.e8

Johnson, K. L., Lero, D. S., \& Rooney, J. A. (2001). Recueil travail-vie 2001: 150 statistiques canadiennes sur le travail, la famille et le bien-être [Report on work-life 2001: 150 Canadian strategies on work, family and well-being]. Canada: Université de Guelph.

Kahn, R. L., Wolfe, D. M., Quinn, R. P., Snoek, J. D., \& Rosenthal, R. A. (1964). Organizational stress: Studies in role conflict and ambiguity. New York: John Wiley \& Sons Inc.

Karasek, R. A., \& Theorell, T. (1990). Healthy Work. Stress, Productivity and the Reconstruction of Working Life. New York: Basic Books.

Karvar, A., \& Rouban. L. (Eds.). (2004). Les cadres au travail. Les nouvelles règles du jeu [Managers at work. 
New game rules]. Paris: La Découverte.

Kelly, E. L., Moena, P., \& Tranbyb, E. (2011). Changing workplaces to reduce work-family conflict: Schedule control in a white-collar organization. American Sociological Review, 76, 265-290. http://dx.doi.org/10.1177/0003122411400056

Korpi, W. (2000). Faces of inequality: Gender, class, and patterns of inequalities in different types of welfare states. Social Politics, 7, 127-191. http://dx.doi.org/10.1093/sp/7.2.127

Kossek, E. E., \& Lautsch, B. A. (2012). Work-family boundary management styles in organizations. A cross-level model. Organizational Psychology Review, 2, 152-171. http://dx.doi.org/10.1177/2041386611436264

Kossek, E. E., Lewis, S., \& Hammer, L. B. (2010). Work-life initiatives and organizational change: Overcoming mixed messages to move from the margin to the mainstream. Human Relations, 63, 3-19. http://dx.doi.org/10.1177/0018726709352385

Kubey, R., \& Csikszentmihalyi, M. (2013). Television and the Quality of Life: How Viewing Shapes Everyday Experience. New Jersey: Routledge.

Lambert, S. J. (1990). Processes linking work and family: A critical review and research agenda. Human Relations, 43, 239-257. http://dx.doi.org/10.1177/001872679004300303

Laurier, E., McKie, L., \& Goodwin, N. (2000). Daily and lifecourse contexts of smoking. Sociology of Health and Illness, 22, 289-309. http://dx.doi.org/10.1111/1467-9566.00205

Lewis, S., \& Cooper, C. (1999). The work-family research agenda in changing contexts. Journal of Occupational Health Psychology, 4, 382-393. http://dx.doi.org/10.1037/1076-8998.4.4.382

Little, L. M., Simmons, B. L., \& Nelson, D. L. (2007). Health Among Leaders: Positive and Negative Affect, Engagement and Burnout, Forgiveness and Revenge. Journal of Management Studies, 44(2), 243-260. http://dx.doi.org/10.1111/j.1467-6486.2007.00687.x

Lundberg, U., \& Frankenhaeuser, M. (1999). Stress and workload of men and women in high-ranking positions, Journal of Occupational Health Psychology, 4, 142-151. http://dx.doi.org/10.1037/1076-8998.4.2.142

Lyons, A. C., \& Chamberlain, K. (2006). Health psychology: A critical introduction. Cambridge: Cambridge University Press. http://dx.doi.org/10.1017/CBO9780511807985

Malrieu, P. (2000). La construction des imaginaires [The construction of imaginaries]. Paris: L'Harmattan.

Marks, D. F. (2002). Freedom, responsibility and power: Contrasting approaches to health psychology (editorial essay). Journal of Health Psychology, 7, 5-19. http://dx.doi.org/10.1177/1359105302007001062

Marks, S. R. (1977). Multiple roles and role strain: Some notes on human energy, time and commitment. American Sociological Review, 42, 921-936. http://dx.doi.org/10.2307/2094577

Mason, J. (1996). Qualitative researching. London: Routledge.

Mead, G. H. (1963). L'esprit, le soi et la société [Mind, self and society]. Paris: P.U.F.

Messing, K. (1999). One-eyed science: Occupational health and women workers. Philadelphia: Temple University Press.

Mielewczyk, F., \& Willig, C. (2007). Old clothes and an older look: The case for a radical makeover in health behaviour research. Theory \& Psychology, 17, 811-837. http://dx.doi.org/10.1177/0959354307083496

Miles, M. B., Huberman, A. M., \& Saldana, J. (2014). Qualitative Data Analysis. A Methods Sourcebook. Thousand Oaks, California: Sage Publications Inc.

Moreno-Jiménez, B., Mayo, M., Sanz-Vergel, A. I., Geurts, S., Rodríguez-Muñoz, A., \& Garrosa, E. (2009). Effects of work-family conflict on employee's well-being: The moderating role of recovery strategies. Journal of Occupational Health Psychology, 14(4), 427-440. http://dx.doi.org/10.1037/a0016739

Newman, D., Tay, B., \& Diener, E. (2014). Leisure and subjective well-being: A model of psychological mechanisms as mediating factors. Journal of Happiness Studies, 15, 555-578. http://dx.doi.org/10.1007/s10902-013-9435-x

Nomaguchi, K. M., Milkie, M. A., \& Bianchi, S. M. (2005). Time strains and psychological well-being: Do dual-earner mothers and fathers differ? Journal of Family Issues, 26, 756-792. http://dx.doi.org/10.1177/0192513X05277524 
OCDE. (2011). Indicators of Gender Equality in Employment. Proportion of men and women with senior $\begin{array}{llll}\text { management } & \text { responsibilities } & \text { 1995-2011. } & \text { Retrieved }\end{array}$ http://www.OECD.org/gender/data/indicatorsofgenderequalityinemployment.htm

Özbilgin, M. F., Beauregard, T. A., Tatli, A., \& Bell, M. P. (2011). Work-life, diversity and intersectionality: A critical review and research agenda. International Journal of Management Review, 13, 177-198. http://dx.doi.org/10.1111/j.1468-2370.2010.00291.x

Pope, C., Ziebland, S., \& Mays, N. (2000). Qualitative research in health care. Analysing qualitative data. BMJ, 320(7227), 114-116. http://dx.doi.org/10.1136/bmj.320.7227.114

Ratner, C. (1997). Cultural Psychology and Qualitative Methodology. New York: Plenum. http://dx.doi.org/10.1007/978-1-4757-2681-7

Rego, A., Pina, E., \& Cunha, M. (2009). Do the opportunities for learning and personal development lead to happiness? It depends on work-family conciliation. Journal of Occupational Health Psychology, 14(3), 334-348. http://dx.doi.org/10.1037/a0014248

Reinert, M. (1998). Mondes lexicaux et topoï dans l'approche Alceste [Lexical worlds and themes in the approach]. In S. Mellet, \& M. Vuillaume (Eds.), Mots chiffrés et déchiffrés, Mélanges offerts à Étienne Brunet [Quantified and unquantified words: a mixed approach for Etienne Brunet] (pp. 289-303). Paris: Champion.

Riegel, K. F. (1976). The dialectics of human development. American Psychologist, 31, 689-700. http://dx.doi.org/10.1037/0003-066X.31.10.689

Riessman, C. K. (2008). Narrative Methods for the Human Sciences. Sage Publications Boston University: USA.

Rossi, M., Borter, S., \& Sasonnens, M. (2012). Female entrepreneurship in Switzerland: Specificities and differences. Journal of Modern Accounting and Auditing, 8(8), 1225-1236. Retrieved from http://www.davidpublishing.com/davidpublishing/journals/J2/acc2011/accountant2011/414.html

Roussillon, R. (1996). Espaces et pratiques institutionnels: Le débarras et l'interstice [Institutional spaces and practices: the storeroom and the interstice]. In R. Kaës, J. Bleger, E. Enriquez, F. Fornari, P. Fustier, R. Roussillon, \& J. P. Vidal (Eds.), L'Institution et les institutions (pp. 157-178). Paris: Dunod.

Santiago-Delefosse, M. (2011). Embodied-socio-psychological perspective. Social and Personality Psychology Compass, 5, 220-230. http://dx.doi.org/10.1111/j.1751-9004.2011.00345.x

Santiago Delefosse, M. (2014). The need for an "embodied socio-psychological" model of illness experience. In M. Murray (Eds.), Manual of Critical Health Psychology (pp. 36-54). London: Palgrave Macmillan.

Sonnentag, S. (2012). Psychological detachment from work during leisure time: The benefits of mentally disengaging from work. Current Directions in Psychological Science, 21, 114-118. http://dx.doi.org/10.1177/0963721411434979

Swiss Employment Law. (2014). Retrieved from http://www.employment-law.ch/particular-contracts-of-employment/part-time-work

The Economist. (2013). Daily chart: The glass-ceiling index. Retrieved from http://www.economist.com/node/21573177/print

Thoenen, O. (2010). Reconciliation of work and family life in Switzerland. German Policy Studies, 6(3), 13-48.

Thompson, J. A., \& Bunderson, J. S. (2001). Work-nonwork conflict and the phenomenology of time. Work and Occupations, 28, 17-39. http://dx.doi.org/10.1177/0730888401028001003

UNECE. (2013). Time use of employed persons by activity and sex. Retrieved from http://w3.unece.org/pxweb/Dialog/Footnote.asp?File=0106_GELB_TUStruct_Empl_r.px\&path=../Database /STAT/30-GE/98-GE_LifeBalance/\&ti=Time+use + of + employed + persons + by + activity + and + sex\&lang=\&an $\mathrm{si}=1 \&$ noofvar $=4 \&$ multilang $=$

Valsiner, J., \& van der Veer, R. (2000). The social mind: Construction of the idea. New York: Cambridge University Press.

Voydanoff, P. (2005). Toward a conceptualization of perceived work-family fit and balance: A demands and resources approach. Journal of Marriage and Family, 67, 822-836. http://dx.doi.org/10.1111/j.1741-3737.2005.00178.x

Vygotski, L. S. (1997). Pensée et langage [Thought and language]. Paris: La Dispute. 
Vygotski, L. S. (1999). La signification historique de la crise en psychologie [Historical meaning of the crisis in psychology]. Lausanne: Delachaux et Niestlé.

Wallon, H. (1942). De l'acte à la pensée. Essai de psychologie comparée [From acting to thinking. Essay on comparative psychology]. Paris: Flammarion.

West, C., \& Zimmerman, D. (1987). Doing gender. Gender and Society, 1, 125-151. http://dx.doi.org/10.1177/0891243287001002002

Willig, C. (2001). Qualitative research in psychology: A practical guide to theory and method. Buckingham: OUP.

\section{Notes}

Note 1. For a complete description of the premises underpinning the characteristics of our methodological design, please refer to: del Rio Carral, 2014.

Note 2. In bold, interventions by the researcher/interviewer.

\section{Appendix A}

\section{Participants' characteristics}

\begin{tabular}{|c|c|c|c|c|c|c|}
\hline & Name* & Life status & $\begin{array}{l}\text { Child(ren) } \\
\text { yes/no }\end{array}$ & $\begin{array}{l}\text { Child(ren)'s } \\
\text { age }\end{array}$ & $\begin{array}{l}\text { Work } \\
\text { rate** }\end{array}$ & Activity sector \\
\hline 1 & Anna & $\begin{array}{l}\text { In } \\
\text { relationship }\end{array}$ & Yes & Under 15 & $\begin{array}{l}\text { full time } \\
(100 \%)\end{array}$ & $\begin{array}{ll}\text { Senior manager of } \\
\text { department } \\
\text { multinational } \\
\text { pharmaceutical } \\
\text { company }\end{array}$ \\
\hline 2 & Beatrice & $\begin{array}{l}\text { In } \\
\text { relationship }\end{array}$ & Yes & Over 15 & $\begin{array}{l}\text { full time } \\
(100 \%)\end{array}$ & $\begin{array}{l}\text { Senior manager of } \\
\text { private company } \\
\text { Services Sector }\end{array}$ \\
\hline 3 & Bernadette & $\begin{array}{l}\text { In } \\
\text { relationship }\end{array}$ & Yes & Under 15 & $\begin{array}{l}\text { full time } \\
(100 \%)\end{array}$ & $\begin{array}{l}\text { Senior manager of } \\
\text { department } \\
\text { multinational } \\
\text { pharmaceutical } \\
\text { company }\end{array}$ \\
\hline 4 & Carla & $\begin{array}{l}\text { In } \\
\text { relationship }\end{array}$ & Yes & Over 15 & $\begin{array}{l}\text { full time } \\
(100 \%)\end{array}$ & $\begin{array}{l}\text { Senior manager of } \\
\text { department } \\
\text { multinational } \\
\text { agri-food company }\end{array}$ \\
\hline 5 & Dalia & $\begin{array}{l}\text { In } \\
\text { relationship }\end{array}$ & Yes & Over 15 & $\begin{array}{l}\text { full time } \\
(100 \%)\end{array}$ & $\begin{array}{l}\text { Senior manager of } \\
\text { department } \\
\text { multinational } \\
\text { agri-food company }\end{array}$ \\
\hline 6 & Diane & $\begin{array}{l}\text { In } \\
\text { relationship }\end{array}$ & Yes & Over 15 & $\begin{array}{l}\text { full time } \\
(100 \%)\end{array}$ & $\begin{array}{l}\text { Senior manager of } \\
\text { department of } \\
\text { Multinational } \\
\text { micro-technology } \\
\text { company }\end{array}$ \\
\hline 7 & Elisa & $\begin{array}{l}\text { In } \\
\text { relationship }\end{array}$ & Yes & Over 15 & $\begin{array}{l}\text { full time } \\
(100 \%)\end{array}$ & $\begin{array}{l}\text { Senior manager of } \\
\text { department of } \\
\text { multinational } \\
\text { pharmaceutical } \\
\text { company }\end{array}$ \\
\hline 8 & Florence & Single & Yes & Over 15 & part time & Senior manager of \\
\hline
\end{tabular}




\begin{tabular}{|c|c|c|c|c|c|c|}
\hline & Name* & Life status & $\begin{array}{l}\text { Child(ren) } \\
\text { yes/no }\end{array}$ & $\begin{array}{l}\text { Child(ren)'s } \\
\text { age }\end{array}$ & $\begin{array}{l}\text { Work } \\
\text { rate** }\end{array}$ & Activity sector \\
\hline & & & & & $\begin{array}{l}\text { (equal to } \\
\text { or more } \\
\text { than } \\
80 \% \text { ) }\end{array}$ & $\begin{array}{lr}\text { department } & \text { of } \\
\text { Public } & \text { Health } \\
\text { sector } & \end{array}$ \\
\hline 9 & Gabrielle & Single & No & none & $\begin{array}{l}\text { full time } \\
(100 \%)\end{array}$ & $\begin{array}{l}\text { Senior manager of } \\
\text { department of } \\
\text { multinational } \\
\text { pharmaceutical } \\
\text { company }\end{array}$ \\
\hline 10 & Greta & $\begin{array}{l}\text { In } \\
\text { relationship }\end{array}$ & Yes & Under 15 & $\begin{array}{l}\text { full time } \\
(100 \%)\end{array}$ & $\begin{array}{l}\text { Senior manager of } \\
\text { department of } \\
\text { multinational } \\
\text { agri-food company }\end{array}$ \\
\hline 11 & Isabelle & $\begin{array}{l}\text { In } \\
\text { relationship }\end{array}$ & Yes & Over 15 & $\begin{array}{l}\text { full time } \\
(100 \%)\end{array}$ & $\begin{array}{l}\text { Senior manager of } \\
\text { department in } \\
\text { public health sector }\end{array}$ \\
\hline 12 & Jeanne & $\begin{array}{l}\text { In } \\
\text { relationship }\end{array}$ & Yes & Under 15 & $\begin{array}{l}\text { part time } \\
\text { (equal to } \\
\text { or more } \\
\text { than } \\
80 \% \text { ) }\end{array}$ & $\begin{array}{ll}\text { Senior manager of } \\
\text { department } \\
\text { Multinational } \\
\text { Agri-food } \\
\text { company }\end{array}$ \\
\hline 13 & Joëlle & Single & No & none & $\begin{array}{l}\text { full time } \\
(100 \%)\end{array}$ & $\begin{array}{l}\text { Senior manager of } \\
\text { department of } \\
\text { multinational } \\
\text { agri-food company }\end{array}$ \\
\hline 14 & Monica & $\begin{array}{l}\text { In } \\
\text { relationship }\end{array}$ & Yes & Over 15 & $\begin{array}{l}\text { full time } \\
(100 \%)\end{array}$ & $\begin{array}{ll}\text { Senior manager of } \\
\text { department of } \\
\text { Multinational } \\
\text { Pharmaceutical } \\
\text { company }\end{array}$ \\
\hline 15 & Patricia & Single & Yes & Under 15 & $\begin{array}{l}\text { part time } \\
\text { (equal to } \\
\text { or more } \\
\text { than } \\
80 \% \text { ) }\end{array}$ & $\begin{array}{l}\text { Senior manager of } \\
\text { private company } \\
\text { Services Sector }\end{array}$ \\
\hline 16 & Rebecca & $\begin{array}{l}\text { In } \\
\text { relationship }\end{array}$ & Yes & Under 15 & $\begin{array}{l}\text { full time } \\
(100 \%)\end{array}$ & $\begin{array}{l}\text { Senior manager of } \\
\text { department of } \\
\text { multinational } \\
\text { agri-food company }\end{array}$ \\
\hline 17 & Sally & Single & No & none & $\begin{array}{l}\text { full time } \\
(100 \%)\end{array}$ & $\begin{array}{l}\text { Senior manager of } \\
\text { department } \\
\text { multinational } \\
\text { pharmaceutical } \\
\text { company }\end{array}$ \\
\hline 18 & Tilda & Single & No & none & $\begin{array}{l}\text { full time } \\
(100 \%)\end{array}$ & $\begin{array}{l}\text { Senior manager of } \\
\text { department } \\
\text { multinational } \\
\text { pharmaceutical } \\
\text { company }\end{array}$ \\
\hline 19 & Valentine & Single & Yes & Over 15 & $\begin{array}{l}\text { full time } \\
(100 \%)\end{array}$ & $\begin{array}{l}\text { Senior manager of } \\
\text { department of } \\
\text { multinational } \\
\text { agri-food company }\end{array}$ \\
\hline
\end{tabular}




\begin{tabular}{lllllll}
\hline & Name* & Life status & $\begin{array}{l}\text { Child(ren) } \\
\text { yes/no }\end{array}$ & $\begin{array}{l}\text { Child(ren)'s } \\
\text { age }\end{array}$ & $\begin{array}{l}\text { Work } \\
\text { rate** }\end{array}$ & Activity sector \\
\hline 20 & Véra & Single & No & None & $\begin{array}{l}\text { full time } \\
(100 \%)\end{array}$ & $\begin{array}{l}\text { Senior manager of } \\
\text { department } \\
\text { of } \\
\text { multinational } \\
\text { agri-food company }\end{array}$ \\
\hline 21 & Violette & Single & No & None & $\begin{array}{l}\text { full time } \\
(100 \%)\end{array}$ & $\begin{array}{l}\text { Senior manager of } \\
\text { department } \\
\text { multinational } \\
\text { agri-food company }\end{array}$ \\
\hline
\end{tabular}

\section{Copyrights}

Copyright for this article is retained by the author(s), with first publication rights granted to the journal.

This is an open-access article distributed under the terms and conditions of the Creative Commons Attribution license (http://creativecommons.org/licenses/by/3.0/). 